\title{
Occurrence of Toxigenic Clostridium difficile in Louisiana Oysters (Crassostrea virginica) and Environmental Waters
}

\author{
Naim Montazeri, Da Liu, Marlene E. Janes* \\ 102 Food Microbiology Laboratory, Agricultural Chemistry Building, School of Nutrition and Food Sciences, \\ College of Agriculture, Louisiana State University/AgCenter, Baton Rouge, Louisiana, USA \\ Email: MJanes@agcenter.Isu.edu
}

Received 10 June 2015, accepted 28 August 2015; published 31 August 2015

Copyright (C) 2015 by authors and Scientific Research Publishing Inc.

This work is licensed under the Creative Commons Attribution International License (CC BY).

http://creativecommons.org/licenses/by/4.0/

(c) (i)

Open Access

\begin{abstract}
Clostridium difficile infection (CDI) was generally considered as a hospital-associated disease; however, recent community-acquired CDI has raised the concerns regarding the transmission of the pathogen through environmental sources. Limited data are available regarding the presence of $\boldsymbol{C}$. difficile in food and water. In this study, oysters (Crassostrea virginica) and the harvest water collected from the commercial harvesting areas along the Louisiana Gulf Coast as well as the influent and effluent of a municipal treatment plant in New Orleans, LA were analyzed for toxigenic C. difficile. The bacterium was isolated from $47.37 \%(9 / 19)$ of oysters and $37.5 \%(3 / 8)$ of harvest water samples. Toxigenic $C$. difficile were also detected in all the wastewater influent and effluent samples. All the isolates harbored the gene $t c d B$ encoding the virulence factor toxin $B$. Further PCR-ribotyping showed that the $C$. difficile isolated from the oysters and harvest water differed from the wastewater isolates. However, similar ribotypes were found in oysters and the surrounding harvest water. We found that oysters growing in contaminated water could bioaccumulate toxigenic $C$. difficile and pose a health risks by serving as a vehicle for the transmission of the pathogen to humans.
\end{abstract}

\section{Keywords}

Clostridium difficile, tcdB Gene, Oyster, Wastewater Treatment Plant, Influent, Effluent

\section{Introduction}

Clostridium difficile is an endospore-forming Gram-positive anaerobic bacillus belonging to the phylum Firmi-

"Corresponding author.

How to cite this paper: Montazeri, N., Liu, D. and Janes, M.E. (2015) Occurrence of Toxigenic Clostridium difficile in Louisiana Oysters (Crassostrea virginica) and Environmental Waters. Food and Nutrition Sciences, 6, 1065-1070.

http://dx.doi.org/10.4236/fns.2015.611110 
cutes. The bacterium colonizes gastrointestinal tract of mammals when the competing micro floras are disrupted. The incidence of disease among human populations frequently occurs in health care systems and/or during a broad-spectrum antibiotic therapy. The infection is usually acquired through the ingestion of the C. difficile transmitted through person-to-person contacts or the environment [1] [2]. Once the spore germinates in the small intestine, toxin-producing $C$. difficile causes a wide range of clinical manifestation in the host from asymptomatic colonization to diarrhea, and even death [3]. Exotoxins A (tcdA) and B (tcdB) and binary toxin (CDT) are the key virulence actors responsible for the pathogenesis of C. difficile [2].

According to a review study, 027 and 078 ribotypes have been associated with the most community-acquired and hospital-acquired $C$. difficile infections (CDI). In this regard, ribotype 078 seems to be more prevalent in community-acquired than that of hospital-acquired CDI [4]. Recent reports on the increment of communityacquired CDI have emphasized on the potential for the transmission of the pathogen through other sources such as animals, foods and water [1] [5]-[7]; however, the occurrence and distribution of the pathogen in such matrices are not adequately investigated. Detection of hypervirulent strains, ribotypes 078 and 027, in meat has raised the concerns regarding the potential of foodborne transmissibility of C. difficile to humans [8] [9], particularly when it was found that conventional cooking methods may not sufficiently eliminate C. difficile spores in meats [10].

Probable resilience of the spores to the wastewater treatment process can contribute to the release of virulent C. difficile strains to the receiving water bodies [11]. Contamination of drinking water with the wastewater effluent caused an outbreak in Finland [7]. C. difficile may either precipitated in the riverbeds or remain suspended and find its way to the coastal seawaters [11] [12]. Filter-feeding bivalve mollusks inhabiting coastal areas can bioaccumulate micro particles, including bacteria and viruses, from the surrounding water, and transmit them to humans [13]. Resistance to adverse conditions enables the spores to last longer than vegetative cells in natural environments. Therefore, conventional non-spore-forming microbial fecal indicators such as fecal coliforms and Escherichia coli may not accurately indicate C. difficile pollution in environment [14]. Few studies have reported the occurrence of $C$. difficile in bivalve mollusks [15] [16]. However, none addressed the presence of the pathogen in oysters and harvest water in the United States. The objective of this study was to investigate the occurrence and of toxigenic $C$. difficile in the Louisiana oysters and the harvest water, as well as the influent and effluent of a secondary municipal wastewater treatment plant in New Orleans, LA. Dominant C. difficile ribotypes were compared among the different sample types.

\section{Material and Methods}

\subsection{Sample Collection}

Oysters (Crassostrea virginica) and harvest water from Louisiana Gulf coast and both influent and effluent waters from a municipal wastewater treatment plant in New Orleans, LA were analyzed for the presence of $C$. difficile. The wastewater is generated from New Orleans on the east bank of the Mississippi River with an estimated population of 378,715 [17]. A $24 \mathrm{~h}$ a day secondary treatment process (an average flow of 98 million gallons per day) employs a high-purity oxygen modification of the activated sludge system, including clarification through sedimentation, chlorination $(0.5 \mathrm{mg} / \mathrm{L})$ for disinfection and finally discharge of effluent directly into the Mississippi River, LA.

Oysters and harvest water samples (Table 1) were collected on a bimonthly basis from five approved commercial harvesting areas (9 through 13) defined by the Molluscan Shellfish program-Louisiana Department of Health and Hospitals (LDHH). Harvest water were grab-sampled followed by dredging the oysters from each site. For the wastewater samples, 24-h composite influent and effluent water samples were collected, monthly, from September 2013 through February 2014. The effluent water samples were dechlorinated by adding 10\% sodium thiosulfate. All the samples were processed and analyzed at the Food Microbiology Laboratory at LSU/Agricultural Center.

\subsection{Sample Processing and $C$. difficile Enrichment}

For each sample, 12 live oysters were shucked; their flesh and intravalvular liquid were collected and blended under sterile condition. One liter of harvest water and $15 \mathrm{~mL}$ of wastewater influent and effluent were passed through a $0.47 \mu \mathrm{m}$ mixed cellulose ester membrane filter (Millipore, Billerica, MA) using a Millipore filtration system (Millipore). The filters were taken aseptically and used for the enrichment. 
Table 1. Occurrence of $C$. difficile in Louisiana oysters and the harvest water.

\begin{tabular}{|c|c|c|c|c|}
\hline Month/year & Harvest area & Coordinates & Oyster & Harvest water \\
\hline January, 2013 & 13 & $29.40147,-90.03231$ & + & NA \\
\hline January, 2013 & 12 & $29.42425,-89.98367$ & + & NA \\
\hline February, 2013 & 13 & $29.40818,-90.00840$ & - & NA \\
\hline March, 2013 & 9 & $29.33497,-89.58835$ & - & NA \\
\hline April, 2013 & 10 & $29.37898,-89.64500$ & + & NA \\
\hline April, 2013 & 11 & $29.36612,-89.66843$ & - & NA \\
\hline June, 2013 & 12 & $29.42071,-89.98174$ & - & NA \\
\hline June, 2013 & 13 & $29.41158,-90.00987$ & - & NA \\
\hline July, 2013 & 9 & $29.33588,-89.59035$ & + & NA \\
\hline July, 2013 & 10 & $29.36766,-89.61490$ & + & NA \\
\hline July, 2013 & 11 & $29.36139,-89.67645$ & + & NA \\
\hline August, 2013 & 12 & $29.46582,-89.97770$ & - & - \\
\hline August, 2013 & 13 & $29.43233,-89.97580$ & + & - \\
\hline September, 2013 & 9 & $29.33515,-89.58707$ & + & + \\
\hline September, 2013 & 10 & $29.37881,-89.64475$ & - & - \\
\hline October, 2013 & 11 & $29.44718,-89.68850$ & - & - \\
\hline November, 2013 & 12 & $29.43075,-89.97806$ & + & + \\
\hline November, 2013 & 13 & $29.39345,-90.00330$ & + & + \\
\hline February, 2014 & 9 & $29.33657,-89.59092$ & - & - \\
\hline
\end{tabular}

Presence and absence of the pathogen is indicated by the positive and negative signs, respectively. NA: data not available.

Brain Heart Infusion (Difco, MD), broth supplemented with $0.1 \%$ sodium taurocholate salt, $8 \mu \mathrm{g} / \mathrm{mL}$ cefoxitin and $250 \mu \mathrm{g} / \mathrm{mL}$ D-cycloserine (Sigma-Aldrich, Germany), was used as a selective enrichment broth for C. difficile. About $50 \mathrm{~g}$ of the oyster homogenate were mixed with $40 \mathrm{~mL}$ of the enrichment broth. For the water samples, the filters were immersed in $40 \mathrm{~mL}$ the enrichment broth. The enrichment cultures were incubated anaerobically at $37^{\circ} \mathrm{C}$ for 10 days. A $96 \%$ ethanol shock $(1: 1, v / v)$ was done for 50 min to eliminate vegetative cells and maintain the spores. Then, the samples were centrifuged at $6000 \times \mathrm{g}$ for $10 \mathrm{~min}$, the supernatant was collected, an aliquot was streak onto C. difficile selective agar (BD, NJ); the plates were incubated for 24 - $48 \mathrm{~h}$ at $37^{\circ} \mathrm{C}$. Following confirmation, DNA from the typical colonies were extracted by UltraClean ${ }^{\mathrm{TM}}$ Microbial DNA Isolation Kit (Mo Bio Laboratories, Solana Beach, CA), and analyzed immediately or stored at $-80^{\circ} \mathrm{C}$ until needed.

\subsection{Detection and Source Tracking of $C$. difficile}

Real-time PCR was used to amplify the 177 bp nonrepeating region of the $t c d B$ gene in C. difficile (Table 2, [18]). The $25 \mu \mathrm{L}$ final reaction mixture was composed of $12.5 \mu \mathrm{L}$ iQ ${ }^{\mathrm{TM}}$ Supermix (Bio-Rad, Veenendaal, The Netherlands), $2.5 \mathrm{pmol}$ of the forward primer (398CLDs), $5.0 \mathrm{pmol}$ of the reverse primer (399CLDas), $4 \mathrm{mM}$ $\mathrm{MgCl}_{2}, 0.2 \mu \mathrm{M} 551 \mathrm{CLD}-\mathrm{tq}-\mathrm{FAM}$ probe, and $2.5 \mu \mathrm{L}$ of DNA template. After an enzyme activation of $3 \mathrm{~min}$ at $95^{\circ} \mathrm{C}$, the PCR protocol consisted of 45 cycles of $30 \mathrm{~s}$ at $94^{\circ} \mathrm{C}, 30 \mathrm{~s}$ at $57^{\circ} \mathrm{C}$, and $30 \mathrm{~s}$ at $72^{\circ} \mathrm{C}$. The PCR was performed using a Cepheid SmartCycler ${ }^{\circledR}$ II system (Sunnyvale, CA). To validate the method, DNA extracted from C. difficile (ATCC 43255), a toxin B-positive strain, and PCR grade water were used as positive and negative controls, respectively. The DNA extracted from the confirmed colonies was subjected to an end-point PCR 
Table 2. Primer and probe sequences used for the detection and ribotyping of $C$. difficile.

\begin{tabular}{ccc}
\hline Primers andprobe $^{1}$ & Sequence (5'-3') & Reference \\
\hline 398CLDs & GAAAGTCCAAGTTTACGCTCAAT & {$[18]$} \\
399CLDas & GCTGCACCTAAACTTACACCA & {$[18]$} \\
551CLD-tq-FAM & FAM-ACAGATGCAGCCAAAGTTGTTGAATT-TAMRA & {$[18]$} \\
16S & 5'-GTGCGGCTGGATCACCTCCT-3' & {$[19]$} \\
23S & 5'-CCCTGCACCCTTAATAACTTGACC-3' & {$[19]$} \\
\hline
\end{tabular}

${ }^{1}$ All primers and probes were purchased from Integrated DNA Technologies (Coralville, IA). FAM, 6-carboxyfluorescein (dye); TAMRA, tetramethylrhodamine (quencher).

to ribotype various strains according to their 16 s and 23s ribosomal RNA sequences (Table 2, [19]). Gel electrophoresis of the PCR amplicons resulted in a DNA fragments pattern that was used to source track the ribotypes across the oysters, harvest water and wastewater samples. According to this method, all the serogroups supposedly result in different patterns except for serogroups H and A8 [19].

\section{Results}

Nine out of 19 oyster samples (47\%), and 3 out of 8 (37\%) harvest water samples were positive for C. difficile (Table 1). Three cases showed the presence of $C$. difficile both in oysters and the harvest waters. All five wastewater influent and effluent samples were tested positive for $C$. difficile. All isolates harbored the gene encoding for toxin B; in particular, according to the real-time PCR of the $t c d B$ sequence, the oysters and harvest water samples crossed the threshold at 38 - 40 cycles, and the wastewater samples crossed the threshold at 24 26 cycles.

Gel images obtained from the electrophoresis of the PCR ribotyping of the C. difficile positive samples indicated the presence of multiple strains (data not shown). Comparison of the banding patterns of the amplified DNA showed that $C$. difficile in oyster or harvest water samples could not be traced back to the sewage influent or effluent waters. However, oyster and harvest water samples collected from the same location showed similar band patterns except for the samples collected from area 12 in November. In some cases, multiple C. difficile strains were found in the oysters collected from the same area at different sampling times such as area 9 in July and September.

\section{Discussions}

C. difficile may represent a minor part of a healthy microbial flora in human's digestive tract. However, under adverse immunological condition of body, this spore-forming anaerobic bacterium can colonize and cause infection. The spores can survive adverse environmental conditions (low or high temperature, dryness, humidity, and chemicals) and transmit to other individuals through contaminated surfaces, food, water or the general environment [12] [14] [20] [21].

In this study, we detected toxigenic $C$. difficile in Louisiana oysters and harvest water collected from commercially active areas, and the influent and effluent waters of a secondary treatment plant in New Orleans (LA). We observed similar toxigenic $C$. difficile ribotypes in all five wastewater samples collected; however, we could not link $C$. difficile ribotypes in the wastewater effluent water to the either oysters or harvest water, consistent with previous reports [11]. The area we investigated was not located at a close distance from the oyster harvest areas, and may not have significantly contributed to its contamination. Since the wastewater we analyzed was generated from the municipal areas, it is expected that the majority of the wastewater influent was limited to human sewage. This could be a reason that we did not find variability in $C$. difficile ribotypes. Our results are comparable with previous studies that reported more than $85 \%$ prevalence of $C$. difficile in wastewater effluents [11] [22] [23]. These observations indicate that $C$. difficile could be resilient to the sewage treatment, and contaminate the environmental waters upon discharge of the effluent water. Filter-feeding molluscan shellfish inhabiting contaminated areas may concentrate pathogenic microorganisms. We found toxin-B positive C. difficile in $47.4 \%$ of the oysters and $37.5 \%$ of the harvest water samples collected from five harvest areas, which is similar 
to the prevalence of $C$. difficile in shellfish in Italy [15]; differently, a lower prevalence of C. difficile (3.6\%) has been reported in bivalve mollusks in Southern Italy [16]. In another study, toxigenic C. difficile is reported in retail scallop, perch, shrimp and salmon in Ontario, Canada [24].

\section{Conclusion}

In conclusion, our study has illustrated that toxigenic C. difficile can be present in untreated (influent) and treated (effluent) wastewaters, oysters and harvest waters. We could not draw a conclusion on the direct effect of wastewater effluent in New Orleans to the contamination of the downstream oyster harvest areas; however, we observed that the oysters growing in the $C$. difficile contaminated areas could bioaccumulate toxigenic $C$. difficile. Overall, our study emphasized on the concerns regarding the potential risk to human health posed by the consumption of raw or partially cooked oysters as well as exposure to sewage-contaminated waters, and their contribution to the community-associated CDI.

\section{Acknowledgements}

This project was partially supported by Agriculture and Food Research Initiative Competitive Grant no. 2011-6800-30395 from the USDA National Institute of Food and Agriculture. The authors would like to thank the funding agency, LSU AgCenter Biotechnology Laboratory, Molluscan Shellfish Program-Louisiana Department of Health and Hospitals and the operating personnel at the wastewater treatment plant.

\section{References}

[1] Lessa, F.C., Mu, Y., Bamberg, W.M., Beldavs, Z.G., Dumyati, G.K., Dunn, J.R., et al. (2015) Burden of Clostridium difficile Infection in the United States. New England Journal of Medicine, 372, 825-834. http://dx.doi.org/10.1056/NEJMoa1408913

[2] Rupnik, M., Wilcox, M.H. and Gerding, D.N. (2009) Clostridium difficile Infection: New Developments in Epidemiology and Pathogenesis. Nature Reviews Microbiology, 7, 526-536. http://dx.doi.org/10.1038/nrmicro2164

[3] Kuijper, E., Coignard, B. and Tüll, P. (2006) Emergence of Clostridium difficile-Associated Disease in North America and Europe. Clinical Microbiology and Infection, 12, 2-18. http://dx.doi.org/10.1111/j.1469-0691.2006.01580.x

[4] Gupta, A. and Khanna, S. (2014) Community-Acquired Clostridium difficile Infection: An Increasing Public Health Threat. Infection and Drug Resistance, 7, 63-72.

[5] de Boer, E., Zwartkruis-Nahuis, A., Heuvelink, A.E., Harmanus, C. and Kuijper, E.J. (2011) Prevalence of Clostridium difficile in Retailed Meat in the Netherlands. International Journal of Food microbiology, 144, 561-564. http://dx.doi.org/10.1016/j.ijfoodmicro.2010.11.007

[6] Khanna, S., Pardi, D.S., Aronson, S.L., Kammer, P.P. and Baddour, L.M. (2012) Outcomes in Community-Acquired Clostridium difficile Infection. Alimentary Pharmacology \& Therapeutics, 35, 613-618. http://dx.doi.org/10.1111/j.1365-2036.2011.04984.x

[7] Kotila, S.M., Pitkanen, T., Brazier, J., Eerola, E., Jalava, J., Kuusi, M., et al. (2013) Clostridium difficile Contamination of Public Tap Water Distribution System during a Waterborne Outbreak in Finland. Scandinavian Journal of Public Health, 41, 541-545. http://dx.doi.org/10.1177/1403494813481648

[8] Jhung, M.A., Thompson, A.D., Killgore, G.E., Zukowski, W.E., Songer, G., Warny, M., et al. (2008) Toxinotype V Clostridium difficile in Humans and Food Animals. Emerging Infectious Diseases, 14, 1039-1045. http://dx.doi.org/10.3201/eid1407.071641

[9] Songer, J.G., Trinh, H.T., Killgore, G.E., Thompson, A.D., McDonald, L.C. and Limbago, B.M. (2009) Clostridium difficile in Retail Meat Products, USA, 2007. Emerging Infectious Diseases, 15, 819-821. http://dx.doi.org/10.3201/eid1505.081071

[10] Rodriguez-Palacios, A., Reid-Smith, R.J., Staempfli, H.R. and Weese, J.S. (2010) Clostridium difficile Survives Minimal Temperature Recommended for Cooking Ground Meats. Anaerobe, 16, 540-542. http://dx.doi.org/10.1016/j.anaerobe.2010.05.004

[11] Xu, C., Weese, J.S., Flemming, C., Odumeru, J. and Warriner, K. (2014) Fate of Clostridium difficile during Wastewater Treatment and Incidence in Southern Ontario Watersheds. Journal of Applied Microbiology, 117, 891-904. http://dx.doi.org/10.1111/jam.12575

[12] Al Saif, N. and Brazier, J.S. (1996) The Distribution of Clostridium difficile in the Environment of South Wales. Journal of Medical Microbiology, 45, 133-137. http://dx.doi.org/10.1099/00222615-45-2-133 
[13] Campos, C.J. and Lees, D.N. (2014) Environmental Transmission of Human Noroviruses in Shellfish Waters. Applied and Environmental Microbiology, 80, 3552-3561. http://dx.doi.org/10.1128/AEM.04188-13

[14] Ashbolt, N.J., Grabow, W.O.K. and Snozzi, M. (2001) Indicators of Microbial Water Quality. In: Fewtrell, L. and Bartram, J., Eds., Water Quality: Guidelines, Standards and Health. Assessment of Risk and Risk Management for WaterRelated Infectious Disease, IWA Publishing, Cornwall, 289-316.

[15] Pasquale, V., Romano, V., Rupnik, M., Capuano, F., Bove, D., Aliberti, F., et al. (2012) Occurrence of Toxigenic Clostridium difficile in Edible Bivalve Molluscs. Food Microbiology, 31, 309-312. http://dx.doi.org/10.1016/j.fm.2012.03.001

[16] Troiano, T., Harmanus, C., Sanders, I.M., Pasquale, V., Dumontet, S., Capuano, F., et al. (2015) Toxigenic Clostridium difficile PCR Ribotypes in Edible Marine Bivalve Molluscs in Italy. International Journal of Food Microbiology, 208, 30-34. http://dx.doi.org/10.1016/j.ijfoodmicro.2015.05.002

[17] U.S. Census Bureau (2013) State and County QuickFacts. http://quickfacts.census.gov/qfd/states/22/2255000.html

[18] van den Berg, R.J., Bruijnesteijn van Coppenraet, L.S., Gerritsen, H.J., Endtz, H.P., van der Vorm, E.R. and Kuijper, E.J. (2005) Prospective Multicenter Evaluation of a New Immunoassay and Real-Time PCR for Rapid Diagnosis of Clostridium difficile_-Associated Diarrhea in Hospitalized Patients. Journal of Clinical Microbiology, 43, 5338-5340. http://dx.doi.org/10.1128/JCM.43.10.5338-5340.2005

[19] Bidet, P., Barbut, F., Lalande, V., Burghoffer, B. and Petit, J.C. (1999) Development of a New PCR-Ribotyping Method for Clostridium difficile Based on Ribosomal RNA Gene Sequencing. FEMS Microbiology Letters, 175, 261-266. http://dx.doi.org/10.1111/j.1574-6968.1999.tb13629.x

[20] Bauer, M.P. and Kuijper, E.J. (2015) Potential Sources of Clostridium difficile in Human Infection. Infectious Disease Clinics of North America, 29, 29-35. http://dx.doi.org/10.1016/j.idc.2014.11.010

[21] Gould, L.H. and Limbago, B. (2010) Clostridium difficile in Food and Domestic Animals: A New Foodborne Pathogen? Clinical Infectious Diseases, 51, 577-582. http://dx.doi.org/10.1086/655692

[22] Steyer, A., Gutierrez-Aguirre, I., Racki, N., Beigot Glaser, S., Humar, B.B., Strazar, M., et al. (2015) The Detection Rate of Enteric Viruses and Clostridium difficile in a Waste Water Treatment Plant Effluent. Food and Environmental Virology, 7, 164-172. http://dx.doi.org/10.1007/s12560-015-9183-7

[23] Romano, V., Pasquale, V., Krovacek, K., Mauri, F., Demarta, A. and Dumontet, S. (2012) Toxigenic Clostridium difficile PCR Ribotypes from Wastewater Treatment Plants in Southern Switzerland. Applied and Environmental Microbiology, 78, 6643-6646. http://dx.doi.org/10.1128/AEM.01379-12

[24] Metcalf, D., Avery, B.P., Janecko, N., Matic, N., Reid-Smith, R. and Weese, J.S. (2011) Clostridium difficile in Seafood and Fish. Anaerobe, 17, 85-86. http://dx.doi.org/10.1016/j.anaerobe.2011.02.008 